\title{
China Facing the Trump Presidency
}

Opportunities for Global Power Projection?

Anthony H. F. Li

\section{(2) OpenEdition}

\section{Journals}

Electronic version

URL: http://journals.openedition.org/chinaperspectives/7357

DOI: $10.4000 /$ chinaperspectives.7357

ISSN: 1996-4617

\section{Publisher}

Centre d'étude français sur la Chine contemporaine

\section{Printed version}

Date of publication: 1 June 2017

Number of pages: 69-73

ISSN: 2070-3449

\section{Electronic reference}

Anthony H. F. Li, «China Facing the Trump Presidency », China Perspectives [Online], 2017/2 | 2017, Online since 01 June 2017, connection on 14 November 2019. URL : http://journals.openedition.org/ chinaperspectives/7357; DOI : 10.4000/chinaperspectives.7357

(C) All rights reserved 


\title{
CefC News Analysis
}

\section{China Facing the Trump Presidency}

\section{Opportunities for Global Power Projection?}

\author{
ANTHONY H. F. LI
}

\section{Introduction}

W hen Donald Trump was elected President of the United States in November 2016, the world was concerned about how he would put into practice the many radical foreign policy ideas that he had proposed during the presidential campaign. Given Trump's hawkish rhetoric toward China, observers paid special attention to how he would change Sino-American relations and how Chinese President $X i$ Jinping would respond. The result of such dynamics will have far-reaching implications for the world. This paper sets out to review Sino-American relations and to assess the challenges and opportunities for China in the areas of national security, economic development, and regional as well as global governance in the early days of Trump's presidency in which new rhetoric and uncertainties overshadow American foreign policy.

\section{Sino-American relations: Between cooperation and competition}

Soon after the establishment of the People's Republic of China, the Beijing government allied with the Soviet Union and labelled the United States an "imperialist force" that endangered its existence in the early period of the Cold War. When Sino-Soviet relations turned sour in the 1960s with the military clash in 1969, the Beijing government and the US Covernment entered into rapprochement and normalised relations in 1979. (1) Subsequently, the US ceased recognition of the Republic of China (Taiwan) under its "OneChina" Policy but continued to maintain non-diplomatic relations with the island under the Taiwan Relations Act.

After the 1989 Tiananmen crackdown, Sino-American relations reached a nadir. Deng Xiaoping proposed the principle of "hiding the light and cultivating one's strength" (tao guang yang hui 韬光养晦) to guide China's foreign policy at the time. In the 1990s, part of the tension in Sino-American relations came from China's human rights record and US trading privileges for China. After heightened tension resulting from the US bombing of the Chinese Embassy in Belgrade in 1999, the two countries continued to engage with each other. In 2001, China became a member of the World Trade Organization with US approval, and they were also drawn into closer cooperation against global terrorism after the 9/11 attacks. As China's comprehensive national power continued to grow from then on, the rhetoric of "peaceful rise" (heping jueqi 和平崛起) became dominant in China's foreign policy discourse, and its national interests also expanded from the regional to the global sphere. Meanwhile, China was encouraged by the US to make a greater contribution to global stability as a means of gaining international recognition as a "responsible power." (2)

After Xi Jinping became China's leader in 2012, there was a change in foreign policy succinctly characterised by the phrase "striving for achievement" (fenfa youwei 奋发有为). ${ }^{(3)}$ In addition to being an international norm-taker, China also strived to be a norm-shaper. ${ }^{\left({ }^{4}\right)}$ For example, Xi announced the establishment of the Asian Infrastructure Investment Bank (AllB) and the "One Belt One Road" (OBOR) initiative in 2013. Moreover, China took a more active role in shaping the rules that regulate cyberspace with the notion of "cyber-sovereignty." (5) With regards to Sino-American relations, Xi proposed a "New Mode of Major Country Relationship" between the two powers, which underlines the principle of "non-conflict, non-confrontation, mutual respect, and win-win cooperation." (6) The US, however, has only accepted such a relationship in part, and its competition with China intensified under the Obama Administration. Since 2011, the US has practiced a "Pivot to Asia" policy and has emphasised its military and economic dominance in Asia. One of its manifestations was the USproposed free trade agreement called the "Trans-Pacific Partnership" (TPP), which deliberately excluded China's participation. It reinforced a prevalent view in China that the grand strategy of the US in Asia was to contain China's rise. ${ }^{(7)}$ Cooperation on specific issues such as climate change has nevertheless been noticeable, and the joint effort of the two countries

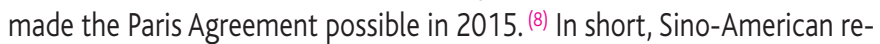
lations could be characterised as between cooperation and competition,

1. David Shambaugh, "Patterns of Interaction in Sino-American Relations," in Thomas W. Robinson and David Shambaugh (eds.), Chinese Foreign Policy: Theory and Practice, New York, Oxford University Press, 1995, pp. 197-223

2. Yong Deng, "China: The Post-Responsible Power," The Washington Quarterly, January 2015, https://twq.elliott.gwu.edu/china-post-responsible-power (accessed on 1 April 2017).

3. Xu Jin, "Zhongguo waijiao Jinru fen fa you wei xin chang tai" (China's diplomacy enters the new normal of "striving for achievement"), China Daily, 16 December 2014, http://column. chinadaily.com.cn/article.php?pid=3264\# (accessed on 20 March 2017).

4. Marc Lanteigne, Chinese Foreign Policy: An Introduction, New York, Routledge, 2016, p. 12.

5. Séverine Arsène, "Internet Domain Names in China: Articulating Local Control with Global Connectivity," China Perspectives, 2015/4, pp. 25-34.

6. Ministry of Foreign Affairs of the People's Republic of China, "Issues on Building a New Model of China-US Major-Country Relationship," 20 March 2016, http://www.fmprc.gov.cn/mfa_eng/ zxxx_662805/t1349547.shtml (accessed on 14 March 2017).

7. Alek Chance, "Interpreting and Misinterpreting 'Lessons Learned' from Obama Pivot," China-US Focus, 2 March 2017, http://www.chinausfocus.com/foreign-policy/interpreting-and-misinterpreting-lessons-learned-from-obama-pivot (accessed on 16 March 2017).

8. Anthony H. F. Li, "Hopes of Limiting Global Warming? China and the Paris Agreement on Climate Change," China Perspectives, 2016/1, pp. 49-54. 
with a practical mix of trust and mistrust. While China is an indispensable power for the US to engage with in trade, global security, and climate change, it also faces frictions with the US on many issues such as territorial assertion, human rights, cyberespionage, currency valuation, etc. ${ }^{(9)}$

\section{President Trump and uncertainties for China}

During the presidential campaign, Donald Trump took advantage of existing Sino-American tensions to castigate China for manipulating its currency, pursuing an imbalance of trade with the US, stealing manufacturing jobs from the US, fabricating the hoax of climate change, etc. ${ }^{(10)}$ He also vowed to put "America first" and to "make America great again" by opposing multilateral free trade and reducing America's international obligations. While it is not uncommon for a president-elect to back down on electoral promises, Trump proved to be an outlier in this regard. However, Trump's determination to realise his non-mainstream views of foreign policy under the catchword "peace through strength" is facing domestic hurdles. For instance, Trump's National Security Council (NSC) and economy-related agencies are manned with people who share his views but also those who do not, hinting at the possibility of foreign policy incoherence. The difficulty Trump had getting the Republican-controlled Congress to approve the trade representative for China he nominated (11) also indicates a potential rift between the White House and Congress and to some extent within the Republican Party. Moreover, Trump himself appears to disregard many conventions in international relations and behaves unpredictably when it comes to foreign affairs, as exemplified in the first Xi-Trump Summit in April 2017, during which Trump ordered a surprise airstrike against Syria's government forces over the latter's use of chemical weapons in its civil war. ${ }^{(12)}$

\section{Sino-American military conflicts in Asia unavoidable?}

Before Trump's presidency, tension had already been building up in East Asia over Taiwan and the South China Sea. Soon after the independenceleaning Democratic Progressive Party (DPP) gained both the presidency and legislative dominance in Taiwan for the first time in May 2016, its refusal to recognise the "1992 Consensus," which regards Taiwan as part of "One China," deepened the mistrust between Beijing and Taipei. In response, Beijing ceased official cross-strait talks with the Taipei government and actively circumscribed its international space. ${ }^{13)}$ There was no shortage of hawkish statements from the mainland side warning of military force in the event of Taiwan moving toward independence. ${ }^{(14)}$ The fact that Trump had a phone conversation with Taiwanese President Tsai Ing-wen after his presidential victory also invited speculation about a change in America's "One-China" policy, although the US reaffirmed its adherence to the policy soon afterward. (15)

In the meantime, the South China Sea also became an object of SinoAmerican contention when Beijing claimed sovereignty over the area and started to militarise it, while Washington emphasised "the right of innocent passage" of military vessels and contained China through warship deployment. ${ }^{(16)}$ The 2016 ruling of the Tribunal constituted under Annex VII to the United Nations Convention on the Law of the Sea, which technically rejected China's territorial claim over the South China Sea, was largely regarded by China as an American plot. ${ }^{(17)}$ Meanwhile, periodic outbursts of nationalism within China, on both the street and the Internet, occur when- ever China comes into conflict with foreign countries. Regardless of the causes for such phenomena, Xi himself also exhibited nationalistic inclinations in his rhetoric of the "China Dream" and "the rejuvenation of the Chinese nation." These make compromise on Taiwan and the South China Sea as China's identified "core interests" less likely.

Moreover, China's military expenditure grew from 79.8 billion USD in 2005 to 215 billion USD in 2015 (around 2\% of GDP throughout the decade). ${ }^{(18)}$ Specifically, China has been strengthening the People's Liberation Army Navy (PLAN) to protect its maritime trade and energy security. ${ }^{(19)}$ The steady rise in China's military strength has caused uneasiness among neighbouring countries, leading them to invite the US to counter-balance China's military power in Asia. ${ }^{(20)}$ Simon Shen from the Chinese University of Hong Kong has pointed out that one of Xi's foreign policy goals is to be the regional power in Asia where Asian people run affairs for themselves. (21) Xi's rhetoric intends to reduce the influence of the US as the current regional power in Asia while not being regarded as culturally Asian. Given the SinoAmerican competition for regional dominance in Asia, observers have discussed whether the two countries will inevitably fall into the "Thucydides Trap" in which a new rising power is likely to enter into military conflict with the hegemonic power. ${ }^{(22)}$ The general consensus is that neither China nor the US could rationalise going to war with the other.

At the onset of Trump's presidency there was discussion about whether the US would withdraw from Asia and isolate itself under the "America First" policy. Shi Yinhong from Renmin University argues that Trump would be less

9. Wang Jisi, "Da qi ju: Guanyu zhongguo diyuan zhanlüe de ruogan sikao" (The big chessboard: some thoughts about China's geopolitical strategy), Blogger China, 9 October 2016, http:// wangjisi.blogchina.com/882854460.html (accessed on 16 March 2017).

10. Simon Denyer, "Trump Says China Is 'the Best Ever' at Devaluing its Currency," The Washington Post, 27 September 2016, https:/www.washingtonpost.com/news/worldviews/wp/2016/ 09/27/trump-says-china-is-the-best-ever-at-devaluing-its-currency-thats-no-longertrue/?utm_term=.6693cf989cc1 (accessed on 12 April 2017).

11. Mark Lander and Michael D. Shear, "Trump Administration to Take Harder Tack on Trade with China," The New York Times, 6 April 2017, https://www.nytimes.com/2017/04/06/ us/politics/trump-xi-jinping-china-summit-mar-a-lago.html?emc=edit_ae_20170406\&nl= todaysheadlines-asia\&nlid=51320395 (accessed on 8 April 2017).

12. Jane Perlez, "After Xi Leaves U.S., Chinese Media Assail Strike on Syria," The New York Times, 8 April 2017, https://www.nytimes.com/2017/04/08/world/asia/china-xi-jinping-president-trumpxinhua.html (accessed on 19 April 2017).

13. See for example, Allison Lampert and J. R. Wu, "U.N. agency Snubs Taiwan, Recognizing Beijing's 'One China'," Reuters, 23 September 2016, http://www.reuters.com/article/us-taiwan-chinaidUSKCN11T08P (accessed on 8 April 2017).

14. See for example, "Chinese Official Offers Hope on Ties," Taipei Times, 12 March 2017, http://www.taipeitimes.com/News/taiwan/archives/2017/03/12/2003666618 (accessed on 8 April 2017).

15. Ting Shi, "Trump Reaffirms 'One-China' Stance in First Call with Xi," Bloomberg, 10 February 2017, https://www.bloomberg.com/politics/articles/2017-02-10/trump-reaffirms-u-s-one-chinastance-in-first-call-with-xi (accessed on 2 May 2017).

16. Sébastien Colin, "China, the US, and the Law of the Sea," China Perspectives, 2016/2, pp. 57-62.

17. Max Fisher, "The South China Sea: Explaining the Dispute," The New York Times, 14 July 2016, https://www.nytimes.com/2016/07/15/world/asia/south-china-sea-dispute-arbitrationexplained.html?_r=0 (accessed on 27 April 2017).

18. SIPRI Military Expenditure Database, https://www.sipri.org/databases/milex (accessed on 12 April 2017).

19. Serafettin Yilmaz, "The Development of the Chinese Navy and Energy Security," Global Review, 2014, pp. 28-42.

20. Yang Henjun, "Why Are China's Neighbors So Afraid of Her?", The Diplomat, 23 May 2014, http://thediplomat.com/2014/05/why-are-chinas-neighbors-so-afraid-of-her/ (accessed on 8 April 2017).

21. Simon Shen, "Xi Jinping shidai zhongguo waijiao de shi da tese" (Ten Features of China's Diplomacy in Xi Jinping's Era), BBC News, http://www.bbc.com/zhongwen/trad/china/2015/11/ 151116_cr_xijinping_diplomacy (accessed on 9 April 2017).

22. Joseph Nye, "The Kindleberger Trap," China-US Focus, 1 March 2017, http://www. chinausfocus.com/foreign-policy/the-kindleberger-trap (accessed on 10 April 2017). 
likely to oppose China's territorial claims in the South China Sea and elsewhere due to the inconsistent policies the Trump Administration made at home and the turbulence Trump brought to America's traditional alliances. He suggests this would give China some additional strategic opportunities. ${ }^{(23)}$ Other observers, however, warn of continued US containment of China, although in a way different from that of the Obama Administration. Shen Dingli from Fudan University argues that Trump's pragmatism could make US military strategy more aggressive than under his predecessor if Xi fails to reach a consensus with Trump on trade frictions. (24) Ruan Zongze from the government-affiliated China Institute of International Studies contends that Trump continues to see Asia as a strategic focal point, and that his vision for the US in Asia is to ask American allies to bear greater responsibility rather than to withdraw the US completely from the Asia-Pacific. ${ }^{(25)}$

Even if the US keeps its presence in Asia, observers argue that military conflict between two countries remains a slight possibility under the Trump Administration. For one thing, domestic nationalism in China might not pose as great a danger as it seems to foreign policy-making. Zha Wen from the China Foreign Affairs University points out that despite nationalistic protests at home, the mainstream middle class in China holds a more tolerant view of globalisation and less anti-foreign sentiment as they are beneficiaries of China's opening to the world. (26) Also, Andrew Nathan from Columbia University observes that China's policymakers have been prudent and pragmatic in using nationalism for foreign affairs in the past. (27) In the shadow of intra-party factional struggle and economic problems at home, $X i$ has no reason to engage the US in military conflict. It is also in the interest of the Chinese Communist Party (CCP) not to lose its focus on sustainable economic growth as an effective tool for remaining in power. In this light, the adoption of the "Thucydides Trap" in Chinese foreign policy discourse ${ }^{(28)}$ is a genuine reflection of the CCP's effort to avoid military conflict with the US.

Meanwhile, the US is unlikely to wage war with China over Taiwan or the South China Sea despite the hawkish rhetoric of the Trump Administration. For one thing, Amitai Etzioni from George Washington University argues that China is of value to the US in achieving other more important objectives, and picking a military conflict with China is very low in the US agenda. ${ }^{(29)}$ Also, the military technology gap is not large enough for the US to be assured of a decisive victory in a military conflict with China, prompting Tao Wenzhao from the Chinese Academy of Social Sciences to argue that any radical alteration of the current peaceful Sino-American relations is not an option for the US. ${ }^{(30)}$

\section{Sino-American trade war in the making?}

Observers then turn to the possibility of a trade war between China and the US, as Trump virtually vowed to start one during the presidential campaign. While economic measures against China were not implemented immediately after his assumption of office, Trump did prepare to find solutions to reduce America's trade deficits with China and other countries. ${ }^{(31)}$ Trump's picks of key trade personnel also indicate his intention to adopt a tougher stance toward China over trade friction. However, as both China and the US are among each other's top five trading partners and export markets, their high level of economic interdependence prompts most scholars to conclude that a trade war between the two would hurt both sides substantially. Also, many cast doubts on whether the US would emerge the ultimate winner in a trade war with China. Given the Chinese state's ability to control its domestic economic market, Keyu jin from the London School of Economics and Political Science contends that the Chinese government could inflict greater harm to the US economy by coordinating its economic retaliation measures more precisely, costing American jobs where Trump vowed to create more. ${ }^{(32)}$ As an alternative to a full-scale trade war, the Trump Administration might initiate trade confrontation in selected sectors, with the steel industry very likely to be one of the targets. ${ }^{(33)}$

There are some less confrontational measures that could reduce trade friction between the two countries. For example, China could remove protectionist measures such as tariffs for American goods and restrictions on American investment in the Chinese market. China could also re-balance bilateral trade by purchasing more high technology from the US and boost investment in the US to help Trump create more jobs. ${ }^{(34)}$ However, the fuzzy linkage between the government and private enterprises in China often sparks national security concerns in the US when Chinese investors acquire American firms with sensitive technologies. Some evidence suggests that China's investment in the US will face even more congressional scrutiny under Trump's presidency. ${ }^{(35)}$ As such, while a full-scale trade war is more unlikely than the rhetoric suggests, trade frictions are inevitable amidst deep-seated Sino-American mistrust, and Trump may continue to hone in on the issue of trade imbalance as a bargaining chip to pressure China for concessions in other areas, as shown in his negotiation with China for deterrence of North Korea's nuclear program after the first Xi-Trump Summit.

23. Andrew Higgins, Neil MacFarquhar, and Jane Perlez, "Where the US Is a Rival, Trump Election Is Greeted with a Smile," The New York Times, 10 November 2016, https://www.nytimes.com/ 2016/11/10/world/trump-putin-xi-america.html (accessed on 8 April 2017).

24. Shen Dingli, "The Future of China-US Relations in the Trump Era," The Diplomat, 4 February 2017, http://thediplomat.com/2017/02/the-future-of-china-us-relations-in-the-trump-era/ (accessed on 9 April 2017).

25. "Te Langpu zhengfu dui yatai zhanlüe de sikao" (Thoughts on the Asia-Pacific strategy of the Trump Administration), Xinhua, 16 March 2017, http://news.xinhuanet.com/asia/201703/16/c_129510579.htm (accessed on 9 April 2017).

26. Zha Wen, "The Coming Clash of Chinese and Western Nationalism," Sixth Tone, 7 March 2017, http://www.sixthtone.com/news/clash-chinese-and-western-nationalism-part-two (accessed on 10 April 2017).

27. Andrew Nathan and Andrew Scobell, China's Search for Security, New York, Columbia University Press, 2014.

28. Gideon Rachman, "Destined for War? China, America and the Thucydides Trap," Financial Times, 31 March 2017, https://www.ft.com/content/0e1ac020-1490-11e7-b0c1-37e417ee6c76 (accessed on 10 April 2017).

29. Amitai Etzioni, "Tillerson, Trump and the South China Sea," The Diplomat, 28 January 2017, http://thediplomat.com/2017/01/tillerson-trump-and-the-south-china-sea/ (accessed on 12 April 2017).

30. Ni Tao, "Sino-US Relations Remain on Solid Footing Despite Trump's Foreign Policy Posture," Shanghai Daily, 16 February 2017, http://www.shanghaidaily.com/opinion/chineseperspectives/SinoUS-relations-remain-on-solid-footing-despite-Trumps-foreign-policyposture/shdaily.shtml (accessed on 12 April 2017).

31. David Lawder, "Trump's Orders Target Trade Abuses, Import Duty Evasion," Reuters, 31 March 2017, http://www.reuters.com/article/us-usa-trump-trade-idUSKBN172080 (accessed on 10 April 2017).

32. Keyu Jin, "China's Weapons of Trade War," Project Syndicate, 22 February 2017, https://www.project-syndicate.org/commentary/china-trump-trade-war-by-keyu-jin-2017-02 (accessed on 10 April 2017)

33. Huang Zhilong, "Cong Te Langpu jingji waijiao tuandui kan 2017 zhongmei maoyuzhan" (Evaluating the Sino-American trade war from Donald Trump's diplomatic team), Caixin, 5 January 2017, http://opinion.caixin.com/2017-01-05/101033512.html (accessed on 10 April 2017).

34. Hu Shuli, "Jushi guanzhu de shou ci xite hui" (World's attention to the first Xi-Trump Summit), Caixin Weekly, http://weekly.caixin.com/2017-04-01/101073501.html (accessed on 10 April 2017).

35. Paul Welitzkin, "Washington Eyes Closer Review of Chinese Investments in US," China Daily, 23 February 2017, http://usa.chinadaily.com.cn/epaper/2017-02/23/content_28320462.htm (accessed on 10 April 2017). 


\section{Regional and global governance: China for leadership?}

Observers are paying attention to whether Trump will uphold the US's leadership role in many aspects of world affairs and whether China will have the interest, capabilities, and sufficient soft power to take up that role in the event of a US retreat.

Regarding regional economic cooperation, Geoffrey Gertz from the Brookings Institute notes that Trump hopes to replace multilateral trade agreements with numerous bilateral deals. He analyses Trump's strategy as likely to be highly inefficient, as it ignores the fact that supply chains for many products have already become globalised, with stages of production taking place in multiple countries. Also, smaller countries find themselves better off under the multilateral framework, as they can form coalitions to offset the power imbalance with major powers such as the US. ${ }^{(36)}$ For this reason, talks on the realisation of the TPP have continued among interested countries following the US's departure, which also allows China greater leeway to shape regional economic rules. China might join the TPP talks and complete the negotiations in the absence of US opposition, or it might push to finalise its own regional free trade agreement, the Regional Comprehensive Economic Partnership (RCEP), which has lower standards for labour protection and intellectual property rights than the TPP. (37)

In global governance, the Trump Administration has exhibited reluctance to uphold some important international commitments such as human rights protection across the world as well as at home. ${ }^{(38)}$ US ambiguity in defending human rights will surely relieve pressure on China regarding its human rights record. This could make China's development model, which emphasises stability over human rights, more attractive globally, and in turn embolden China to further suppress calls for better protection of human rights at home and democratisation in places where it enjoys special influence such as Hong Kong. ${ }^{(39)}$ The "China Model" may even be more actively promoted, as Xi shows a growing interest in "guiding international society" with China's own version of international order. ${ }^{(40)}$

At the World Economic Forum in Davos in January 2017, Xi deliberately seized the moment to advocate the merits of economic globalisation in response to the rise of alt-right nationalism and populism in the US and Europe. His speech, which proposed a "China Solution" to the pressing issues of the world today, also portrayed China as a potential candidate for global leadership ${ }^{(41)}$ and brought Xi surprising media acclaim. ${ }^{(42)}$ Similar to China's official view, John Dickenson from the Chinese Academy of Social Sciences praised Xi for taking responsibility for safeguarding the international public good and for establishing a new discourse emphasising cooperation for mutual benefit. ${ }^{(43)}$ Some Chinese scholars also suggest that China should be more active in promoting a new Sino-centric international order with "rule by Chinese virtues" (wangdao) instead of "rule by Western coercive force" (badao). (44) Such endeavours for ideological and cultural justification of China's new role in the international community should nevertheless be subject to further scrutiny about how China lives up to those values empirically abroad and at home. Elizabeth Economy of the Council on Foreign Relations on the other hand cautions against rapid embrace of China's qualifications as a defedner of globalism. She argues that China's restrictive policies on the flow of goods, capital, and information make it far from a "champion of globalisation" at this moment. ${ }^{(45)}$ Jean-Pierre Cabestan from Baptist University of Hong Kong also questions whether Western countries would follow China's proposal of a state-controlled rather than society- based international order, and suggests that America's global leadership could experience resurgence with the eventual departure of Trump, as its political system is more resilient than China's in maintaining military and economic power. ${ }^{(46)}$

With regards to climate change, the looming possibility that the US will not honour the Paris Agreement has brought China and the European Union closer together to fill the leadership void. ${ }^{(47)}$ Nicholas Stern from the London School of Economics and Political Science believes that China has the capacity to be a leader on this front due to its constant effort in promoting sustainable energy. ${ }^{(48)}$

The US commitment to global security is less evident since Trump's presidency, causing some eyes to shift to China. However, while China is currently the third largest contributor to the UN budget and second largest to the UN peacekeeping force, ${ }^{(49)}$ it is doubtful whether China is both willing and able to contribute to global security. On the issue of non-proliferation of nuclear weapons, while both China and the US adopt the same rhetoric, Luo Xi from the Academy of Military Science of China points out that China's scope of focus is less extensive than that of the US and is largely restricted to North Korea due to its geopolitical importance. North Korea's continued nuclearisation over the past years has also exposed the deficiency of China's policy toward this issue. (50) Even if China's leaders want to be more active in this role, the potential overstretching of China's current do-

36. Geoffrey Gertz, "What Will Trump's Embrace of Bilateralism Mean for America's Trade Partners?", The Brookings Institute, 8 February 2017, https://www.brookings.edu/blog/futuredevelopment/2017/02/08/what-will-trumps-embrace-of-bilateralism-mean-for-americas-tradepartners/ (accessed on 11 April 2017)

37. Finbarr Bermingham, "China and Korea Join TPP Negotiations in Chile," Global Trade Review, 14 March 2017, http://www.gtreview.com/news/asia/china-and-korea-join-tpp-negotiations-inchile/ (accessed on 11 April 2017).

38. "11-Country Letter Stirs Fears on U.S. Rights Stance," China Digital Times, 21 March 2017, http://chinadigitaltimes.net/2017/03/11-country-letter-china-stirs-fears-u-s-rights-stance/ (accessed on 11 April 2017).

39. Andrew Nathan, "China's Challenge," in Larry Diamond, Marc Plattner, and Christopher Walker (eds.), Authoritarianism Goes Global: The Challenge to Democracy, Baltimore, John Hopkins University Press, 2016, pp. 31-32.

40. "Is China Challenging the United States for Global Leadership?", The Economist, 1 April 2017, http://www.economist.com/news/china/21719828-xi-jinping-talks-china-solution-withoutspecifying-what-means-china-challenging (accessed on 19 April 2017).

41. "Xi Jinping ruishi yanjiang" (Xi Jinping's Speech in Switzerland), China Central Television, 20 January 2017, http://news.cctv.com/2017/01/20/ARTljfFM72a0RpxBRW5NWlvX170120.shtml (accessed on 12 April 2017)

42. Tom Philips, "How Xi Jinping's Global Ambitions Could Thrive as Trump Turns Inward," The Guardian, 10 February 2017, https://www.theguardian.com/world/2017/feb/10/how-xi-jinpings-globalambitions-could-thrive-as-trump-turns-inward (accessed on 19 April 2017).

43. John Dickenson, "Xi Jinping's Role in China, and China's Role in the World," World Economic Forum, 16 January 2016, https://www.weforum.org/agenda/2017/01/xijinping-china-role/ (accessed on 12 April 2017).

44. See for example, Yan Xuetong, Xia yi ge shi nian: quanqiu bianju da yuce (The next decade: The forecast of global order), Taipei, Gusa Publishing, 2013.

45. Elizabeth Economy, "Beijing Is No Champion of Globalization," Foreign Affairs, 22 January 2017, https://www.foreignaffairs.com/articles/china/2017-01-22/beijing-no-champion-globalization (accessed on 12 April 2017)

46. Jean-Pierre Cabestan, "Is the Trump Era Really the Xi Era?" A China File Conversation, 1 March 2017, https://www.chinafile.com/conversation/trump-era-really-xi-era (accessed on 12 April 2017).

47. Alissa de Carbonnel, "Faced with U.S. Retreat on Climate Change, EU Looks to China," Reuters, 1 February 2017, http://www.reuters.com/article/us-usa-trump-eu-climatechange-idUSKBN15C $5 B 3$ (accessed on 11 April 2017).

48. Nicholas Stern, "China Is Shaping up to Be a World Leader on Climate Change," Financial Times, 20 January 2017, https://www.ft.com/content/3f1ba5ba-ddac-11e6-86ac-f253db7791c6 (accessed on 11 April 2017).

49. "Is China Challenging the United States for Global Leadership?", art. cit.

50. Luo Xi, "Push and Pull: Factors for China-U.S. Cooperation on North Korea," China-US Focus, 5 April 2017, http://www.chinausfocus.com/foreign-policy/push-and-pull-factors-for-china-uscooperation-on-north-korea (accessed on 12 April 2017). 
mestic strength for such tasks calls for a careful re-consideration. ${ }^{(51)}$ Joseph Nye from Harvard University also warns that overestimation of China's role in providing global security might repeat the mistake made in the interwar period, when the US bound itself to isolationism and the United Kingdom was unable to play such a role, ultimately leading to a disastrous outcome. ${ }^{(52)}$

\section{Conclusion}

With Trump's determination to bring about the radical changes he envisions and the unpredictability of US foreign policy filled with new rhetoric, it is hard to predict the future of Sino-American relations. Room for both competition and cooperation co-exist. In the areas where competition is inevitable, ensuring that miscalculation does not prevail is of importance. In the Sino-American competition for Asian dominance, Trump's hawkish rhetoric, even if not realised at the end, could push more hawkish elements within China such as the People's Liberation Army to gain greater weight in forging foreign policy. ${ }^{\left({ }^{53}\right)}$ The result could put China, the US, and Asian countries in a "security dilemma" that no country rationally desires.

Meanwhile, the Trump Administration's unpredictability in foreign affairs could increase miscalculations for its Chinese counterpart. As the rhetoric of Western interference in China's domestic affairs has been frequently deployed to justify the tightening of domestic control since the Xi Administration, China's miscalculation of the US security policy might arouse greater suspicions about the US's "ulterior motives" toward China. There could be some unintended consequences. For one thing, it could unnecessarily reduce the Sino-American exchanges that have been beneficial to China's socioeconomic development. Also, it would sustain Beijing's hard-line policies toward Taiwan and Hong Kong, where historical relations with the US have always complicated Beijing's strategies toward the two places, and where local resistance to China's increasing encroachment is already evident. Mistaken assessment of the threat they pose to China's national security could backfire on China's long-term policy to win the hearts and minds of the local populace and further foment anti-China sentiments there.

On the economic front, if Sino-American trade friction seems unavoidable given domestic politics in the US and Trump's diplomatic strategies, greater
US pressure on China is not necessarily negative, as it could help China reconsider the setbacks of its heavy trade imbalance with the US and to leverage external stimuli to push ahead with necessary economic reforms currently blocked by domestic vested interests or by Chinese officials obsessed with China's new international status and resistant to new ideas from the outside world. ${ }^{\left({ }^{4}\right)}$ As the Chinese writer Lu Xun once said, Chinese people opt for moderate reform in the face of revolutionary change. If you want to open a window against the darkness, you are likely to be rejected, but if you say you want to remove the rooftop for light, you will get the window opened. (55)

Moreover, in the event of a US retreat from global leadership, China's greater cooperation with other countries on climate change and regional free-trade frameworks could enhance China's political influence by filling the leadership vacuum in those multilateral discussions. Nevertheless, China's unilateral use of trade, investment, and its domestic market as foreign policy tools to punish other countries for perceived violation of its "core interests" could undermine the faith of other countries in China's qualifications to become a global leader.

Furthermore, it remains to be seen whether China is willing to take a more active role in global security such as nuclear non-proliferation and global terrorism beyond its national interests, and whether it is capable of mustering sufficient support from the international community, where prevalent values and norms are sometimes at odds with those upheld in China.

Lastly, despite all the rhetoric of Sino-American competition in the early days of Trump's presidency, it is certainly possible that the two countries could enter a period of greater cooperation through a number of "grand deals" between Xi Jinping and Donald Trump by favouring pragmatism over idealism in guiding foreign affairs and turning zero-sum competition into positive-sum cooperation. In the short-term, reduction in Sino-American competition is likely to afford China a balance of power favourable for its continued projection of power in Asia and beyond.

CEFC News Analysis is compiled from the CEFC's fortnightly selection of Press Highlights, available at www.cefc.com.hk.

51. Stephen Roach, "The Temptations of a Resilient China," Project Syndicate, 27 March 2017, https://www.project-syndicate.org/commentary/resilient-china-global-power-temptation-bystephen-s-roach-2017-03 (accessed on 29 April 2017).

52. Joseph Nye, "The Kindleberger Trap," art. cit.

53. Jing Sun, "Growing Diplomacy, Retreating Diplomats: How the Chinese Foreign Ministry Has Been Marginalized in Foreign Policymaking," Journal of Contemporary China,Vol. 26, Issue 105, 2017, pp. 419-433.

54. Wang Xiangwei, "Forget the Hype about Leading the World, China Has to Get its Own House in Order," South China Morning Post, 1 April 2017, http://www.scmp.com/week-asia/opinion/article/2083450/opinion-forget-hype-about-leading-world-china-has-get-its-own (accessed on 19 April 2017).

55. Lu Xun, The Complete Works of Lu Xun's Essay, Beijing, Yanshan Press, 2011, p. 531. 